\title{
PENGARUH SISTEM PENYALURAN KREDIT TERHADAP KEPUASAN ANGGOTA CREDIT UNION KARYA MURNI MEDAN
}

\author{
Nawary Saragih \\ Universitas Katolik Santo Thomas Medan Jl. Setia Budi No. 479F, 20132, Indonesia \\ e-mail: nawary_saragih@yahoo.com
}

\begin{abstract}
Credit Union (CU) Karya Murni Medan is a business engaged in lending and receiving deposits. Members of the CU often complain because of the vulnerable process of administering credit until the disbursement phase, resulting in members less satisfied with the credit distribution system set by the $C U$. From the problem identification, formulated the research problem is "Does the credit channeling system have a significant influence on the satisfaction of CU members" .The research hypothesis "Is there any effect of credit distribution system on the satisfaction of CU members". The purpose of this study is to determine the effect of credit distribution system on the satisfaction of CU members. The benefits of research is to increase insight and knowledge of the author on the influence of credit distribution system to the satisfaction of CU members. The study population is all members of CUtahun 2016 as many as 7200 people. The sample was taken 96 people with maximum error sampling. Data collection techniques are documentation techniques and questionnaires. Data analysis technique used is simple linear regression analysis. Conclusion: The credit disbursement system in CU has not been optimally satisfying the members, due to the length of time span between applications with credit realization. The credit interest rate offered is higher than other $C U$. Members of CU complain that they are not responding quickly enough to complain, if the application is approved, it is obliged to pay the administrative fee. The equations are $y=0.727+0.803 . x$. That is, the credit channeling system has a positive effect on the satisfaction of CU members. The correlation coefficient value is 0.769 . That is, the credit channeling system has a positive relationship to the satisfaction of CU members. Determinant coefficient value of 0,591, meaning that member satisfaction can be explained by credit distribution system equal to 59,1\% while 40,9\% again explained by other factor. The test results $z$-count $=11.646>$ $z$ table $=0,000$, then $\mathrm{HO}$ is rejected. That is, the credit channeling system has a significant effect on the satisfaction of CU members, can be accepted at a significance level of 5\%. Suggestion as information material. Instead, $\mathrm{CU}$ will accelerate the decision making of credit realization, to maintain member loyalty. Preferably, CU decreases loan interest rates in anticipation of the shift of members to other CUs that offer lower interest rates. To increase member satisfaction, CU should waive members on the credit administration costs. Because satisfaction on credit distribution system there are other factors as much as $40.9 \%$, then CU Management should be in overcoming it requires system improvement and service improvement in various fields.
\end{abstract}

Keywords: Credit distribution system, satisfaction of members of CU Karya Murni Medan

\section{PENDAHULUAN}

Pada saat ini telah banyak usaha yang bergerak di bidang penyaluran kredit, misalnya Bank, Koperasi, dan lain sebagainya.Dalam menjalankan aktivitasnya, tentu usaha tersebut berusaha melayani Nasabah atau Anggotanya sebaik mungkin, dengan pelayanan yang baik, para Nasabah/ Anggotanya merasa puas.Lembaga keuangan merupakan salah satu faktor yang mempengaruhi perkembangan perekonomian Nasional.Kehadiran usaha ini, bukanlah sekedar alat untuk membiayai aktivitas ekonomi saja, tetapi juga merupakan faktor yang sangat penting dalam pembangunan.Oleh karena itu perbankan atau koperasi dapat membantu masyarakat yang membutuhkan dana dalam bentuk kredit. Walau demikian untuk mendapatkan kredit tersebut tidaklah mudah, karena harus memenuhi syarat yang ditetapkan pihak Bank atau Koperasi.

Setiap Bank atau Koperasi menawarkan kredit dengan cara yang berbeda dan mempunyai sistem penyaluran yang berbeda pula. Sistem penyaluran kredit merupakan 
suatu cara penyampaian kredit kepada calon Nasabah atau Anggota yang dapat memenuhi syarat yang ditetapkan. Secara khusus, keinginan Nasabah atau Anggota meminjam adalah dengan mempertimbangkan kemampuannya melunasi dengan kemudahan administrasi kredit, biaya administrasi dan suku bunga kredit.

Kepuasan dari Nasabah Bank atau Anggota Koperasi yaitu tingkat perasaan seseorang setelah membandingkan kinerja yang dia rasakan melebihi dengan harapannya.Jika sistem penyaluran kredit yang ditawarkan oleh Bank atau Koperasi sesuai harapannya, maka mereka merasa puas dan jika sistem penyaluran kredit yang ditawarkan tidak sesuai harapan mereka, maka mereka merasa tidak puas.

Kepuasan dan ketidakpuasan dari Nasabah atau Anggota atas penyaluran kredit yang ditawarkan oleh pemberi kredit akan diceritakan kepada keluarga, rekan bisnis, dan sahabat mereka. Hal ini akan berakibat pada perkembangan usaha tersebut di masa mendatang. Menurut Rangkuti (2003:31), faktor-faktor yang mempengaruhi kepuasan pelanggan adalah nilai, daya saing, persepsi pelanggan, harga dan citra serta tahap pelayanan".

Koperasi Kredit (simpan pinjam) yang disingkat CU (Credit Union) adalah sebuah lembaga keuangan yang bergerak dibidang simpan pinjam yang dimiliki dan dikelola oleh Anggotanya bertujuan mensejahterakan Anggotanya sendiri yang merupakan pelaku usaha kecil menengah (UKM).http://mesinpercetakan.com/koperasi-credit-union-indonesia

CU Karya Murni Medan adalah usaha yang bergerak dalam pemberian pinjaman dan menerima simpanan wajib dan sukarela berupa tabungan. Dana yang tersedia di CU ini disalurkan kembali kepada anggota dalam bentuk kredit. Kredit yang disalurkan adalah untuk kredit produktif, yaitu kredit yang diberikan untuk memperlancar ekonomi atau usaha anggotanya. Pinjaman ini diberikan kepada pedagang yang pembayarannya dilakukan secara bulanan, sedangkan Kredit konsumtif, yaitu pinjaman yang diberikan kepada anggota untuk membiayai suatu kebutuhan yang bersifat konsumtif seperti pembelian tanah, rumah, kendaraan dan kebutuhan lainnya, pembayarannya dilakukan tiap bulan.

Dari hasil penelitian diketahui bahwa jumlah anggota pada CU Karya Murni Medan, tahun 2015 sebanyak 7.243 orang, tahun 2016 menurun menjadi 7.200 orang. Penurunan ini disebabkan karena waktu yang dibutuhkan mulai dari permohonan sampai realisasi kredit membutuhkan waktu yang relatif lama, karena setelah persyaratan yang ditetapkan CU dipenuhi oleh Anggota, kemudian pihak CU melakukan rapat dan survei berdasarkan prinsip 5C (character, capacity, capital, condition dan colateral).

Setiap organisasi dalam menjalankan usahanya sebagai lembaga keuangan yang menyimpan dan menyalurkan kredit kepada masyarakat pasti menghadapi masalah yang perlu diselesaikan. Anggota CU Karya Murni Medan sering mengeluh karena lamanya proses administrasi pengajuan kredit sampai pada tahap pencairan dana. Akibatnya Anggota kurang puas atas sistem penyaluran kredit yang ditetapkan oleh CU Karya Murni Medan.

Berdasarkan uraian di atas, penulis tertarik melakukan penelitian ini dengan judul: "Pengaruh sistem penyaluran kredit terhadap kepuasan Angota CU Karya Murni Medan".

\section{TINJAUAN PUSTAKA}

\section{A. Pengertian Koperasi simpan pinjam}

Koperasi simpan pinjam bertugas memberikan pelayanan masyarakat, berupa pinjaman dan tempat penyimpanan uang bagi masyarakat. Sumber dana koperasi simpan pinjam, diproleh dari simpanan sukarela anggotanya dan berbagai lembaga pemerintah, maupun lembaga swasta yang mengalami kelebihan dana. Secara umum, sumber dana koperasi berasal dari anggota sendiri berupa simpanan pokok, simpanan wajib dan simpanan sukarela.

\section{B. Peranan Koperasi simpan pinjam}




\section{Volume 18 Nomor 1}

a. Peranan koperasi simpan pinjam yaitu ikut mengembangkan perekonomian masyarakat terutama bagi para anggotanya, antara lain :

Membantu keperluan kredit para anggota dengan syarat-syarat yang ringan.

b. Mendidik para anggotanya supaya giat menabung secarateratur sehingga membentuk modal sendiri.

c. Menambah pengetahuan tentang perkoperasian.

d. Menjauhkan anggotanya dari cengkeraman rentenir atau tengkulak

\section{Manfaat koperasi simpan pinjam}

Pada koperasi simpan pinjam ini ada manfaat bagi anggota:

a. Anggota dapat memperoleh pinjaman dengan mudah dan tidak berbelit-belit

b. Proses bunganya adil karena disepakati dalam rapat anggota tahunan (RAT)

c. Jaminan sebagai syarat meminjam sifatnya situasional.

\section{Pengertian dan Unsur-unsur kredit}

Istilah kredit dari bahasa latin(credere) yang berarti kepercayaan (truth atau faith). Oleh karena itu dasar dari kredit adalah kepercayaan seseorang atau suatu badan yang memberikan kredit percaya bahwa penerima kredit di masa mendatang sanggup memenuhi segala sesuatu yang telah dijanjikan.

Menurut Tohar (2000:18) "kredit adalah pinjaman kepada pihak pertama yang berjangka, baik jangka panjang, jangka menengah dan jangka pendek. Menurut Rachmat dkk, (2004:2) "kredit adalah sistem keuangan untuk mempermudah pemindahan modal dari pemilik kepada pemakai dengan pengharapan memperoleh keuntungan. Kredit diberikan berdasarkan kepercayaan orang lain yang memberikannya terhadap kecakapan dan kejujuran sipeminjam".

\section{E. Jenis-jenis Kredit}

Menurut Kasmir (2001:99), jenis-jenis kredit dilihat dari berbagai segi antara lain:

1. Dilihat dari segi kegunaan.

a. Kredit investasi. Biasanya digunakan untuk keperluan perluasan usaha atau membangun proyek atau pabrik baru atau untuk keperluan rehabitasi. Contoh kredit investasi misalnya untuk membangun pabrik atau membeli mesin-mesin. Masa pemakaiannya untuk suatu periode yang relatif lama.

b. Kredit modal kerja. Digunakan untuk keperluan meningkatkan produksi dalam operasionalnya. Sebagai contoh kredit modal kerja diberikan untuk membeli bahan baku, membayar gaji atau biaya lain yang berkaitan dengan proses produksi.

2. Dilihat dari tujuan kredit.

a. Kredit produktif. Kredit yang digunakan untuk peningkatan usaha atau produksi atau investasi. Kredit ini diberikan untuk menghasilkan barang dan jasa. Sebagai contoh kredit untuk membangun pabrik yang akan menghasilkan barang, kredit pertanian untuk menghasilkan produk pertanian atau kredit pertambangan menghasilkan bahan tambang atau kredit industri lainnya.

b. Kredit konsumsi. Kredit yang digunakan untuk dikonsumsi secara pribadi. Dalam kredit ini tidak ada pertambahan barang dan jasa yang dihasilkan, karena memang untuk digunakan atau dipakai oleh seseorang atau badan usaha. Sebagai contoh kredit perumahan, kredit mobil pribadi, kredit perabotan rumah tangga dan kredit konsumtif lainnya.

c. Kredit perdagangan. Kredit yang digunakan untuk perdagangan, biasanya untuk membeli barang dagangan yang pembayarannya diharapkan dari hasil penjualan barang dagangan tersebut. Kredit ini sering diberikan kepada supplier atau agen-agen 
perdagangan yang akan membeli barang dalam jumlah besar. Contoh kredit ini misalnya kredit ekspor dan impor.

3. Dilihat dari jangka waktu. Jangka waktu pemberian kredit dapat dibagi atas tiga yaitu:

a. Kredit jangka pendek (short term-loan) yaitu kredit yang jangka waktu pengembali annya kurang dari satu tahun. Misalnya kredit untuk membiayai kelancaran operasi perusahaan termasuk kredit modal kerja.

b. Kredit jangka menengah (medium term-loan) yaitu kredit yang jangka waktu pengembaliannya 1 sampai 3 tahun. Biasanya kredit ini untuk menambah modal kerja misalnya untk membiayai pengadaan bahan baku.

c. Kredit jangka panjang (long term-loan) yaitu kredit yang jangka waktu pengembaliannya melebihi tiga tahun. Misalnya kredit investasi yaitu kredit untuk membiayai suatu proyek perluasan usaha atau rehabilitasi.

4. Dilihat dari segi jaminan.

a. Kredit dengan jaminan. Kredit yang diberikan dengan suatu jaminan, dapat berbentuk barang berwujud atau tidak berwujud atau jaminan orang. Artinya setiap kredit yang dikeluarkan akan dilindungi senilai jaminan yang diberikan si calon debitur.

b. Kredit tanpa jaminan, merupakan kredit yang diberikan tanpa jaminan barang atau orang tertentu. Kredit jenis ini diberikan dengan melihat prospek usaha dan karakter serta loyalitas atau nama baik si calon debitur selama ini.

5. Dilihat dari segi sektor usaha.

a. Kredit pertanian, merupakan kredit yang dibiayai untuk sektor perkebunan atau pertanian lainnya.

b. Kredit peternakan, dalam hal ini untuk jangka pendek misanya peternakan ayam dan jangka panjang kambing dan sapi.

c. Kredit industri, yaitu kredit untuk membiayai industri kecil, menengah atau besar.

d. Kredit pertambangan, jenis usaha tambang yang dibiayainya biasanya dalam jangka panjang, seperti tambang emas, minyak atau timah.

e. Kredit pendidikan, merupakan kredit yang diberikan untuk membangun sarana dan prasarana pendidikan atau kredit untuk para mahasiswa.

f. Kredit profesi, diberikan kepada para profesional seperti dosen, dokter atau pengacara.

g. Kredit perumahan, yaitu kredit untuk membiayai pembangunan atau pembelian perumahan.

\section{F. Prinsip Pemberian kredit}

Kepercayaan kepada sipenerima kredit ditetapkan dengan memiliki waktu dan kemampuan modalnya.Waktu pemberian kredit dapat berlangsung beberapa saat saja dan bahkan sampai bertahun-tahun, sehingga transaksi kredit tersebut mengandung suatu tingkat rasio tertentu, baik bagi si pemberi maupun si penerima kredit.

Menurut Tohar (2000:20), untuk melaksanakan kegiatan pengkreditan secara sehat, pemberian kredit biasanya menggunakan prinsip 5C yaitu :

1. Character yaitu mengenai sifat-sifat peminjam, seperti kejujuran, ambisi, tanggung jawab, kemampuan, meyakinkan orang. Penilaian ini dilakukan untuk mencoba memperkirakan kemungkinan Anggota mau memenuhi kewajibannya. Faktor ini sangat penting, karena setiap transaksi kredit merupakan suatu janji untuk membayar apakah penerima kredit berusaha keras untuk membayar hutangnya, atau ia mencoba untuk menghindarinya. Manfaat penilaian ini adalah untuk mengetahui tingkat kejujuran dan integrasi serta tekad baik dari calon peminjam.

2. Capacity yaitu calon peminjam untuk memperoleh keuntungan dari usahanya kecakapan bertindak cepat dan tepat dalam menghadapi keadaan yang mendesak. Penilaian ini 
dilakukan untuk menilai sejauh mana calon peminjam mampu melunasi kewajibannya tepat pada waktunya.

3. Capital yaitu jumlah modal yang dimilki calon peminjam, modal diukur dengan posisi keuangan perusahaan secara umum yang disimpulkan dari analisa rasio keuangan dengan penekanan khususnya pada modal bersih peminjam.

4. Collateral yaitu kemampuan jaminan yang tersedia dan nilai serta kualitasnya dalam menutup resiko yang terjadi.

5. Condition yaitu kemampuan calon peminjam menghadapi dan mengatasi perubahan situasi lingkungan yang mempengaruhi kegiatan usahanya.

Selain memperhatikan syarat $5 \mathrm{C}$, juga memperhatikan pedoman $3 \mathrm{R}$ dalam penilaian penggunaan kredit yaitu:

1. Return merupakan hasil yang diharapkan dapat mempertahankan dari penggunaan kredit tersebut dalam hubungan ini sangat baik harus menilai bagaimana kredit diperoleh dari Koperasi tersebut akan digunakan oleh pemohon kredit. Maksudnya adalah apakah penggunaan kredit tersebut akan menghasilkan pendapatan yang cukup untuk menutupi biayanya.

2. Repayment capacity, artinya Koperasi harus memiliki kemampuan pemohon kredit untuk membayar kembali pinjaman saat kredit harus diangsur atau dilunasi.

3. Risk bearning ability, artinya Koperasi harus menilai apakah pemohon kredit mempunyai kemampuan untuk menanggung resiko kegagalan atau ketidak pastian dengan penggunan kredit tersebut. Dalam hubungan ini Koperasi harus mengetahui tentang pinjaman tersebut oleh pemohon kredit.

\section{G. Sistem Penyaluran Kredit}

Syarat atau penunjuk tindakanyang harus dilakukan sejak diajukan permohonan Anggota sampai pelunasannya suatu kredit yang diberikan oleh Koperasi telah dibuat dalam suatu ketentuan prosedur.Menurut Suyatno, dkk., (2007:70), permohonan kredit meliputi:

1. Pengertian. Permohonan fasilitas kredit mencakup:
a. Permohonan baru untuk mendapat suatu jenis fasilitas kredit
b. Permohonan tambahan suatu kredit yang sedang berjalan
c. Permohonan perpanjangan atau pembaharuan masa kredit yang telah berakhir jangka waktunya.
d. Permohonan lainnya untuk perubahan syarat-syarat fasilitas kredit yang sedang berjalan, antara lain penukaran jaminan, perubahan atau pengunduran jadwal angsuran dan lain sebagainya.

2. Berkas. Setiap berkas permohonan kredit dari Anggota terdiri dari surat permohonan Anggota yang ditandatangi lengkap dan sah, daftar isian yang disediakan oleh Koperasi serta daftar lampiran yang diperlukan menurut jenis fasilitas kredit.

3. Pencatatan. Setiap surat permohonan kredit yang diterima harus dicatat dalam register khusus yang disediakan.

4. Kelengkapan dan permohonan kredit. Permohonan kredit dinyatakan lengkap bila telah memenuhi persyaratan yang ditentukan untuk pengajuan permohonan menurut jenis kreditnya.

5. Formulir daftar isian kredit. Untuk memudahkan Koperasi memperoleh data, Koperasi menggunakan daftar isian permohonan kredit yang harus diisi oleh Anggota.

Menurut Suyatno, dkk., (2007:70), penyelidikan (investigasi kredit adalah pekerjaan yang meliputi:

1. Pengertian dan ketentuan

a. Penyelidikan (investigasi) kredit adalah pekerjaan yang meliputi:

1) Wawancara dengan pemohon kredit atau debitur. 
2) Pengumpulkan data yang berhubungan dengan permohonan kredit yang diajukan Anggota, baik data intern Koperasi maupun data ekstern. Dalam hal ini termasuk informasi antar Koperasi, dan pemeriksaan pada daftar-daftar hitam dan daftardaftar kredit yang macet.

3) Pemeriksaan atau penyelidikan atas kebenaran dan kewajiban mengenai hal-hal yang dikemukakan Anggota dan informasi lainnya yang diperoleh.

4) Penyusunan laporan seperlunya mengenai hasil penyelidikan.

b. Analisis kredit merupakan pekerjaan yang meliputi: persiapan pekerjaan dari segala aspek, baik keuangan maupun non keuangan untuk mengetahui kemungkinan dapat atau tidak dapat dipertimbangkan permohonan kredit.

c. Pekerjaan penyelidikan dilakukan petugas yang berfungsi sebagai penyelidik kredit, sedangkan pekerjaan analisis dilakukan oleh kredit analisis. Pembagian kerja tersebut apabila organisasi bagian kredit memungkinkannya.

2. Berkas dan pencatatan. Berkas permohonan dan dokumen laporan penyelidikan bersifat rahasia. Petugas analisis memelihara catatan-catatan seperlunya mengenai pekerjaan nya, sehingga dapat dijadikan sebagai alat untuk mengetahui dan menafsirkan pekerjaan yang sudah dan sedang dilakukannya.

3. Data pokok minimal dan analisis pendahuluan. Pada saat berlaku ketentuan bahwa usulan fasilitas kredit harus memuat data pokok minimal mengenai aktivitas usaha, disertai dengan analisis seperlunya.

4. Penelitian data. Koperasi perlu mengadakan penelitian yang semestinya atas kewajaran dan konsistensi dari data dan informasi yang diterima dari Anggota sebelum mengadakan analisis yang ditentukan. Hal ini dilakukan untuk mencegah kesimpulan yang kurang tepat serta memperlambat pengambilan keputusan.

5. Penelitian atas realisasi usaha. Data-data realisasi pembelian, produksi dan penjualan dalam minimal tiga bulan terakhir, hendaknya dibandingkan dengan realisasi bulan sebelumnya, baik dalam kuantum maupun nilai rupiahnya. Perbandingan dengan aktivitas rekening untuk pinjaman-pinjaman yang sedang berjalan akan sangat bermanfaat.

6. Penelitian atas rencana usaha. Rencana-rencana aktivitas (minimal 6 bulan mendatang) perlu mendapat penelaahan yang seksama, dan membandingkannya dengan perkembangan pada bulan sebelumnya, baik dalam nilai maupun dalam kuantitas.

7. Penelitian dan penilaian barang-barang jaminan tambahan. Pada tempatnyalah bila jaminan-jaminan tambahan yang ditawarkan atau pada saat pertama kalinya dijaminkan, mendapat pemeriksaan yang semestinya dari pejabat Koperasi. Dalam penyajian data kepada pejabat yang berhak memutuskan, petugas kredit sudah harus mensortir jenisjenis barang yang dapat diikat sebagai jaminan secara juridis perfect saja.

8. Penelitian pendahuluan atas laporan keuangan. Laporan keuangan yang diterima dari Anggota harus mendapat perhatian mengenai kebenaran dan kewajarannya. Untuk laporan keuangan yang telah diaudit oleh akuntan publik, penelitiannya tidak sesukar laporan keuangan yang dibuat sendiri oleh perusahaan.

9. Analisis kebutuhan kredit. Untuk kredit investasi, petugas kredit harus menyampaikan analisis kebutuhan investasi berupa:

a. Perhitungan dan perincian secara cermat atas investasi yang diperlukan antara lain ialah barang yang akan dibeli, dibangun atau direhabilitasi, harga satuan dan jumlah yang didasarkan atas surat penawaran dari pihak ketiga, saham, serta pembiayaan Anggota, kewajaran dan kebenaran data yang diterima dari Anggota dan sebagainya.

b. Cash flow projection adalah mutlak harus disampaikan karena pendekatan ini merupakan cara yang cocok, baik dalam menetapkan jadwal pencairan kredit, maupun dalam mengukur jangka waktu, pemakaian kredit serta kemampuan pelunasannya.

Menurut Suyatno, dkk., (2007:76), keputusan permohonan kredit mencakup: 
1. Pengertian

Keputusan adalah setiap tindakan pejabat yang berdasarkan wewenangnya berhak mengambil keputusan berupa menolak, menyetujui, dan atau mengusulkan permohonan fasilitas kredit kepada pejabat yang lebih tinggi.

2. Bahan pertimbangan pengambilan keputusan.

Setiap keputusan permohonan kredit, harus memperhatikan penilaian syarat-syarat umum yang ada pada dasarnya tercantum dalam laporan pemeriksaan kredit dan analisis kredit. Bahan pertimbangan atau informasi-informasi lainnya yang diperoleh pejabat pengambil keputusan, harus dibubuhkan secara tertulis.

3. Wewenang mengambil keputusan.

a. Wewenang Kepala Bagian Kredit atau Cabang.

1) Sampai dengan jumlah permohonan dalam jenis krdit yang dintenkan oleh direksi/kantor pusat, kepala bagian kredit atau kepala cabang diberi wewenang untuk memutuskan permohonan dalam batas-batas tertentu tanpa mengusulkan terlebih dahulu kepada kantor pusat.

2) Jika permohonan berada di luar batas wewenangnya, cabang harus mengusulkan terlebih dahulu permohonan fasilitas kredit tersebut kepada direksi/kantor pusat disertai hasil penilaian serta kesimpulan-kesimpulan dan usul-usul yang definitif.

b. Wewenang Direksi/Kantor Pusat

Direksi/kantor pusat memberikan keputusan permohonan fasilitas kredit yang dilakukan bagian kredit/cabang setelah mengadakan penilaian permohonan fasilitas kredit yang diusulkan.

4. Laporan penggunaan wewenang.

a. Setiap keputusan yang diambil oleh bagian kredit/cabang dalam hubungannya dengan wewenangnya, baik berupa perstujuan maupun penolakan atas permohonan kredit, harus dilaporkan ke direksi atau kantor pusat yang umumnya berupa tembusan, serta tindakan analisis lengkap. Setelah itu dikirim ke biro yang membidanginya.

b. Setiap keputusan harus diberitahukan kepada pemohon secara tertulis.

Persetujuan permohonan kredit merupakan keputusan Koperasi untuk mengabulkan sebagian atau seluruh permohonan kredit dari calon debitur. Untuk melindungi kepentingan Koperasi dalam pelaksanaan persetujuan tersebut, maka biasanya ditegaskan terlebih dulu syarat-syarat fasilitas kredit dan prosedur yang harus ditempuh oleh Anggota.

\section{H. Kepuasan Anggota}

Lupiyoadi (2001:158), mengatakan bahwa "kepuasan merupakan tingkat perasaan dimana seseorang menyatakan hasil perbandingan atas kinerja atau jasa yang diterima dan diharapkan".Lebih lanjut, Kotler (2000:52), mengatakan bahwa "kepuasan adalah tingkat perasaan seseorang setelah membandingkan kinerja (hasil) yang dia rasakan dibandingkan dengan harapannya".

Berdasarkan pengertian di atas, dapat dikatakan bahwa kepuasan Anggota merupakan pemahaman tentang kebutuhan dan keinginan para pelanggan melalui produk yang dihasilkan.Kepuasan Anggota berkaitan dengan persepsi Anggota atas produk yang berguna untuk memenuhi kebutuhan dan keinginannya.Produk yang berkualitas dengan harga yang relatif rendah dan mudah diperoleh jika diperlukan, hal ini dapat memberi kepuasan kepada para Anggota untuk memenuhi dan keinginannya.

\section{METODOLOGI PENELITIAN}

\section{A. Desain Penelitian}

Metode penelitian adalah salah satu cara yang sifatnya sistematika dan objektif dengan tujuan untuk memperoleh, mengumpulkan informasi atau data-data yang diteliti secara 
efisien, yang dapat digunakan sebagai pedoman dalam melaksanakan penelitian. Metode penelitian ini meliputi: populasi dan sampel, operasionalisasi variabel, teknik pengumpulan data, teknik analisis data dan hipotesis.

\section{B. Metode Penarikan Sampel}

Populasi dalam penelitian ini adalah keseluruhan objek yang diteliti atau diamati. Populasi dalam penelitian ini adalah seluruh Anggota CU tahun 2016 sebanyak 7200 orang. Metode penarikan sampel yang dipakai dalam penelitian ini adalah ditentukan berdasarkan kesalahan maksimum yang diinginkan(samplingerror), dengan rumus (Supranto, 2009:113), maka jumlah sampel yang dibutuhkan $(n)=96,04$ dibulatkan menjadi 96 orang.

\section{Operasionalisasi Variabel}

Defenisi operasionalisasi variabel yang diteliti sebagai berikut:

1. Sistem penyaluran kredit $(X)$ yaitu setiap kegiatan yang diperuntukkan atau ditujukan untuk memberikan kepuasan Anggota, melalui sistem penyaluran kredit yang dapat memenuhi kebutuhan dan keinginan Anggota. Dengan indikator: Kemudahan persyaratan kredit,Variasi jangka waktu kredit, Bunga kredit, Kemudahan prosedur permohonan kredit, Rentang waktu antara permohonan dengan realisasi kredit, Sistem pembayaran cicilan, Ketepatan taksiran nilai Agunan.

2. Kepuasan Anggota $(\mathrm{Y})$ yaitu tingkat perasaan seseorang setelah membandingkan kinerja (hasil) yang dia rasakan dibandingkan dengan harapannya. Dengan indikator: Kejelasan informasi, Banyaknya jenis kredit yang ditawarkan, Keakuratan pencatatan transaksi, Citra, Biaya administrasi, Besarnya denda tunggakan kredit, Penanganan keluhan

\section{Teknik Pengumpulan Data}

Teknik pengumpulan data yang digunakan adalah kuesioner. Kuesioner dilakukan dengan membagikan angket kepada Anggota CU. Daftar kuesioner dibuat dalam bentuk pertanyaan tertutup dengan mencantumkan beberapa pilihan jawaban dan Responden cukup memilih salah satu jawaban yang paling tepat dan pertanyaan terbuka untuk menambah ketajaman analisis dalam pembahasan untuk saran yang tidak terkoper oleh peneliti. Setelah daftar kuesioner diisi, kemudian ditabulasi kembali untuk dioleh dengan SPSS versi 22.0 dan dianalisis lebih lanjut untuk menarik kesimpulan dan saran.

\section{E. Metode Analisis Data}

a. Uji Validitasi. Uji validitas berguna untuk menguji ketepatan hasil kuesioner. Menurut Sugiyono (2005:114)."jumlah anggota sampel digunakan sekitar 30 orang". Biasanya, syarat minimum yang dianggap memenuhi syarat adalah kalau $r=0,3$. Jika korelasi antara butir dengan skor total kurang dari 0,3, maka butir dalam instrumen tersebut dinyatakan tidak valid.

b. Uji Reliabilitas. Menurut Sugiyono (2005:122), “pengujian reliabilitas dengan internal consistency, dilakukan dengan cara mencoba instrumen sekali saja, kemudian data yang diperoleh dianalisis dengan teknik tertentu". Hasil analisis dapat digunakan untuk memprediksi reliabilitas instrumen.Pada pengujian ini jika $\alpha>0,50$ artinya instrumen reliabel, jika $\alpha<0,50$ artinya instrumen tidak reliabel.

c. Analisis Regresi Linier Sederhana. Analisis ini dimaksudkan untuk mengetahui besarnya pengaruh sistem penyaluran kredit terhadap kepuasan Anggota dengan menggunakan rumus regresi linear sederhana yang dikutip dari J.Supranto (2016:185): $y=a+b . x$. Keterangan rumus diaplikasikan dalam penelitian ini sebagai berikut:Y=Kepuasan Anggota, $x=$ Sistem penyaluran kredit, $a=$ Nilai Konstanta, $b=$ Koefisien regresi, $n=J u m l a h$ sampel 


\section{HASIL ANALISIS DAN PEMBAHASAN}

\section{A. Hasil Penelitian}

1. Uji Validitas dan Reliabilitas. Hasil pengujian terhadap validitas dan reabilitas menunjukkan bahwa seluruh indikator pengukuran sistem penyaluran kredit sudah valid dan reliabel, karena nilai korelasi hitung semua di atas 0,30 dan nilai alpha cronbach'slebih besar 0,50.

2. Pengujian Hipotesis. Hasil analisis regresi linear sederhana denganmengolah data menggunakan program SPSS versi 22.00 didapatkan hasil diperoleh $Y=0,727+0,803$.X. Artinya, sistem penyaluran kredit berpengaruh positif terhadap kepuasan Anggota CU. Nilai koefisien korelasi sebesar 0,769.Artinya, sistem penyaluran kredit mempunyai hubungan positif terhadap kepuasan Anggota CU. Nilai koefisien determinan sebesar 0,591.Artinya kepuasan Anggota dapat dijelaskan oleh sistem penyaluran kredit sebesar $59,1 \%$ sedangkan 40,9\% lagi dijelaskan oleh faktor lain, seperti keadaan ekonomi nasional.

Berdasarkan hasil pengujian diperoleh $\mathrm{z}$-hitung $=11,646>\mathrm{z}$-tabel $=0,000$, sehingga $\mathrm{H}_{0}$ ditolak dan $\mathrm{H}_{1}$ diterima. Artinya, sistem penyaluran kredit mempunyai pengaruh yang signifikan terhadap kepuasan Anggota CU, dapat diterima pada tingkat signifikansi 5\%.

\section{B. Pembahasan}

\section{Sistem Penyaluran Kredit}

CU Karya Murni Medan memberikan pelayanan yang baik kepada masyarakat secara efesien dan terkendali.CU memberikan kredit kepada anggota masyarakat sebagai pribadi maupun sebagai pengusaha kecil yang membutuhkan dana.

Salah satu kegiatan CUadalah menyalurkan kembali dana ke masyarakat. Kredit adalah penyediaan uang atau tagihan yang dapat disamakan dengan itu berdasarkan persetujuan pinjam meminjam antar Koperasi dengan pihak lain. Dalam hal ini pihak peminjam berkewajiban melunasi hutangnya setelah jangka waktu tertentu dengan bunga yang ditentukan. Dengan ketentuan :

a. Kredit harus mendapat persetujuan panitia kredit, Bendahara dan Ketua.

b. Petugas meminjamkan boleh diberi wewenang untuk memberikan dengan surat perjanjian pinjaman dengan pinjaman.

c. Pemeriksaan pinjaman wajib dilakukan terhadap anggota untuk mengecek kebenaran data tersebut.

CU juga mencegah orang-orang rentenir, maka operasional Koperasi ini lebih berperan demi menciptakan masyarakat adil dan makmur. Dalam hal ini pemberian kredit mengutamakan pada masyarakat ekonomi lemah dalam usahanya untuk memperbaiki perekonomian rakyat banyak.

CU Karya Murni Medan menawarkan jangka waktu kredit dengan keanekaragaman jangka waktu kredit dalam pembayarannya, pihak CU mengharapkan anggota dapat menyesuaian jangka waktu kredit yang diambilnya dengan mempertimbangkan kemampuannya untuk membayar. CU menetapkan bunga kredit sebesar 3\% per bulan atau $36 \%$ per tahun.

Prosedur pemberian kredit dan realisasi kredit pada CU Karya Murni Medan adalah:

a. Permohonan kredit yang telah disetujui oleh Panitia Kredit, maka dibuat surat persetujuan kredit.

b. Bendahara, sebelum mencairkan kredit yang diajukan oleh debitur, terlebih dahulu memeriksa kelengkapan atau pengisian permohonan kredit dan meminta persetujuan dari Kreditur. Dalam hal ini, sebagai bukti persetujuan pencairan kredit, maka pihak yang berwenang (Ketua) menandatangani berkas, dan selanjutnya Bendaharamenjelaskan isi perjanjian kredit kepada anggota. Bendahara menginstruksikan kepada Kasir untuk mencairkan dana sesuai jumlah kredit yang disetujui kepada anggota. 


\section{Volume 18 Nomor 1}

c. Kasir berfungsi untuk mengeluarkan sejumlah uang kepada anggota sesuai bukti realisasi persetujuan kredit yang diterima dari Bendahara setelah ditanda tangani oleh Ketua.

Proses permohonan dan realisasi kredit CU Karya Murni Medan disajikan oleh penulis seperti pada alur berikut:

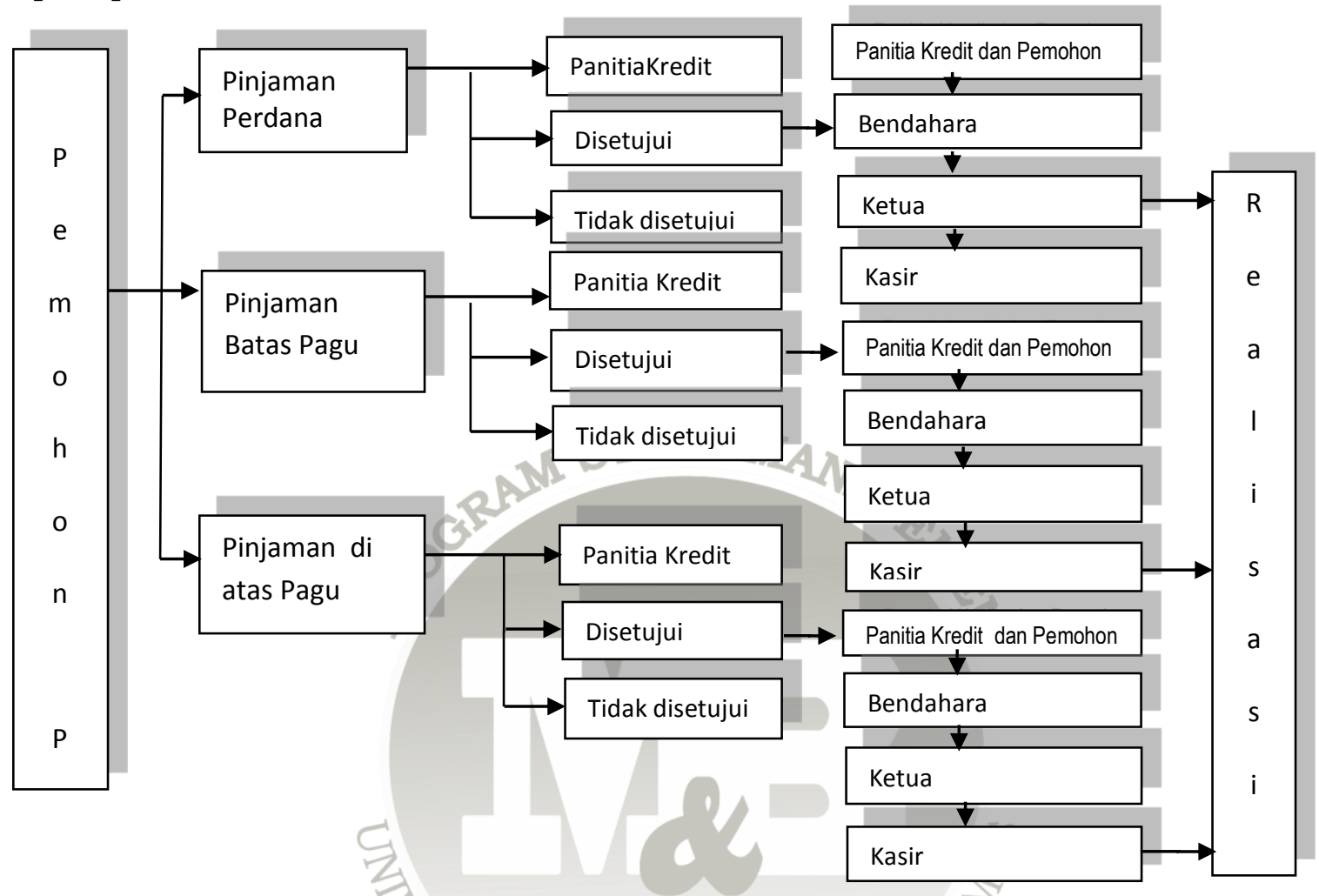

Gambar 1 Tahap Awal Tahap Proses Tahap Permohonan Penyelesaian Sumber: Hasil Olahan Penulis Dari Sop Cu Karya Murni Medan

Penyelesaian kredit berarti anggota telah memenuhi semua kewajibannya kepada Koperasi. Kredit selesai bilamana seluruh kewajiban anggota berupa pokok pinjaman, bunga dan denda (jika ada) serta biaya administrasi telah dilunasi seluruhnya. Untuk mencegah timbulnya klaim dari anggota karena tidak lengkapnya pengembalian dokumen jaminan, maka pihak Koperasi mengadakan inventarisasi atas dokumen yang disimpan pada berkas jaminan dan dicocokkan dengan catatan yang tersedia. Penyerahan jaminan yang diberikan oleh anggota harus disertai dengan tanda terima dan ditandatangani oleh yang berhak. Setelah pelunasan kredit dilakukan oleh anggota, maka pengambilan dokumen jaminan hanya dapat dilakukan dengan sepengetahuan dari Ketua.

\section{Kepuasan Anggota}

Manajemen CUberusaha meningkatkan kepuasan Anggota berupa kejelasan informasi yang diberikan oleh karyawan kepada anggota saat meminta persyaratan yang harus dipenuhi untuk mendapatkan kredit.Koperasi menawarkan berbagai jenis kredit, sehingga calon debitur dapat memilihnya.Dalam penyaluran kredit, pihak Koperasi mewajibkan pegawai melakukan pencatatan transaksi.

KaryawanCU menjamin keakuratan pencatatan transaksi yang dilakukan oleh anggota, misalnya pada saat anggota membayar cicilan beserta bunga pinjaman, Kasir harus mencatatnya sebagai pengurang utang anggota. Selanjutnya, Kasir juga memberikan bukti pembayaran kredit kepada anggota.

Pengurus CU berusaha menjaga citranya melalui pemberian pelayanan kepada anggota secara cepat dan tepat waktu. Pada saat permohonan kredit disetujui dan 
ditandatangani perjanjian, maka anggota dibebankan biaya administrasi. Setiap anggota yang menunggak, diwajibkan membayar denda sebesar $2 \%$ dari cicilan per bulan. Untuk meningkatkan kepuasan anggotaCU berusaha semaksimal mungkin menyelesaikan keluhan anggota secepatnya.

Menurut ketentuan CUdiketahui bahwawaktu yang dibutuhkan mulai dari permohonan sampai realisasi kredit bisa mencapai mingguan. Akibatnya, Anggota merasa kurang puas hal ini dapat dilihat dari menurunkan jumlah Anggota, yaitu dari tahun 2015 sebanyak 7.243 orangmenurun menjadi 7.200 orang pada tahun 2016.

\section{Analisis Kuesioner Tentang Sistem Penyaluran Kredit}

Persamaan regresi linear sederhana adalah $Y=0,727+0,803 . X$. Artinya, sistem penyaluran kredit berpengaruh positif terhadap kepuasan AnggotaCU. Hal ini dapat dilihat dari nilai koefisien regresinya yang bertanda positif.

Dari persamaan regresi linear tersebut terlihat bahwa besar pengaruh sistem penyaluran kredit terhadap kepuasan Anggota sebesar 0,803. Artinya, jika sistem penyaluran kredit baik, maka kepuasan Anggota akan meningkat sebesar 0,803. Dengan demikian, berarti terdapat pengaruh positif antara sistem penyaluran kredit terhadap kepuasan Anggota.

Dari hasil pengujian diperoleh $\mathrm{z}$-hitung $=11,646>\mathrm{z}$-tabel $=0,000$, sehingga $\mathrm{H}_{0}$ ditolak dan $\mathrm{H}_{1}$ diterima. Artinya, sistem penyaluran kredit mempunyai pengaruh yang signifikan terhadap kepuasan AnggotaCU. Dengan demikian, hipotesispenelitian diterima.

\section{KESIMPULAN}

Berdasarkan hasil pembahasan yang telah dilakukan, disimpulkan bahwa:

1. Sistem penyaluran kredit pada CU belum optimal memuaskan anggota, karena rentang waktu antara permohonan dengan realisasi kredit bisa mencapai 14 hari.suku bunga kredit yang ditawarkan lebih tinggi dari CU lain

2. Hasil kuesioner, menunjukkan bahwa anggotaCU masih ada keluhan, karena kurang cepat menanggapi keluhan, jika permohonan anggota yang disetujui diwajibkan membayar biaya administrasi pada saat pencairan kredit.

3. Persamaan regresi linear sederhana bahwa $y=0,727+0,803 . x$. Artinya, sistem penyaluran kredit berpengaruh positif terhadap kepuasan anggota pada CU Karya Murni Medan. Dilihat dari nilai koefisien regresinya yang bertanda positif.

4. Nilai koefisien korelasi sebesar 0,769. Artinya, sistem penyaluran kredit mempunyai hubungan positif terhadap kepuasan anggota pada CU Karya Murni Medan.

5. Nilai koefisien determinan sebesar 0,591, artinya kepuasan anggota dapat dijelaskan oleh sistem penyaluran kredit sebesar 59,1\% sedangkan 40,9\% lagi dijelaskan oleh faktor lain, seperti keadaan ekonomi nasional.

6. Hasil pengujian diperoleh $\mathrm{z}$-hitung $=11,646>\mathrm{z}$ tabel $=0,000$, sehingga $\mathrm{H}_{0}$ ditolak dan $\mathrm{H}_{1}$ diterima. Artinya, sistem penyaluran kredit mempunyai pengaruh yang signifikan terhadap kepuasan anggotaCU, dapat diterima pada tingkat signifikansi 5\%.

\section{DAFTAR PUSTAKA}

Kasmir, 2003. Koperasi dan Lembaga Keuangan Lainnya. Edisi Keenam, Cetakan Ketujuh, Jakarta:Raja Granfindo Persada.

Lupiyoadi, Rambat, 2001. Manajemen Pemasaran Jasa:Teori dan Praktik, Edisi Pertama, Cetakan Pertama, Jakarta:Salemba Empat.

Rachmat, dkk, 2004 Manajemen Perkreditan Koperasi Umum, Edisi Kedua Bandung: Afabeta. 
Rangkuti, Freddy, 2003. Measuring Customer Satissfaction: Teknik mengukur dan Strategi Meningkatkan Kepuasan Konsumen Plus Analisis Kasus PLN-JP, Jakarta: PT Gramedia Pustaka Utama.

Sugiyono, 2005. Metode Penelitian Administrasi, Edisi Kedua Belas, Bandung: CV Alfabeta. Supranto, J 2016. Stasistik:Teori dan Aplikasi, Jilid 1, Edisi 8, Jakarta: Erlangga.

-----2009. Stasistik:Teori dan Aplikasi, Jilid 2, Edisi Ketujuh, Jakarta: Erlangga.

Suyatno, Thomas, dkk, 2007. Dasar-dasar Perkreditan, Jakarta: Gramedia Pustaka Utama.

Tohar, M, 2000. Permodalan dan Perkreditan, Edisi Ketiga, Yogyakarta:Kanisius.

Umar, Husein, 2003. Studi Kelayakan Bisnis. Edisi Pertama, Cetakan Pertama, Jakarta: PT.

Gramedia Pustaka Utama.

Untung, 2005. Dasar-dasar pengkreditan. PT. Gramedia Jakarta.

Download:

www.google.pengertian+koperasi+simpan+pinjam

https://id.wikipedia.org/wiki/Koperasi_kredit

http://mesinpercetakan.com/ koperasi-credit-union-indonesia

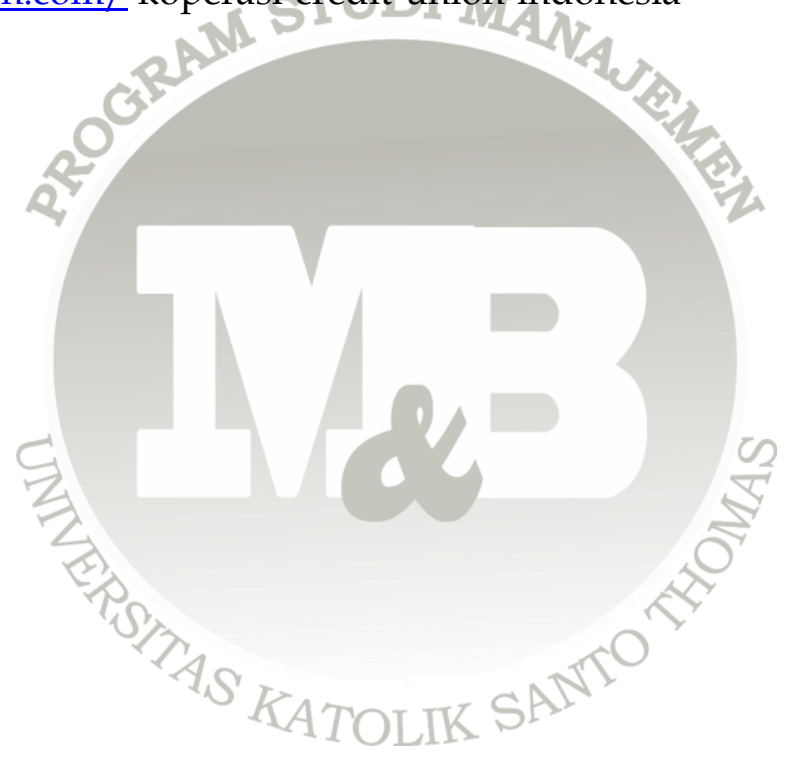

